\title{
FEATURES OF THE CULTURE AND LANGUAGE OF THE GEORGIAN PEOPLE
}

\author{
(C) Dinara Ya. Gordienko, Elmira A. Imanmagomedova, Aida I. Akavova
}

\author{
Rostov State University of Economics, Rostov-on-Don; \\ Dagestan State Medical University, Dagestan State \\ University of National Economy, Makhachkala, \\ Dagestan Republic, Russian Federation \\ science-almanac@mail.ru
}

\begin{abstract}
Culture is made up of many elements. Some of the elements are more obvious, others less: clothing, language, food, customs, beliefs, values, religious beliefs, superstitions, etc. In recent years, there has been an increase in academic interest in the culture and heritage of the Black Sea region. The increased emphasis and interest in issues of national identity in the states of the region have made a significant contribution to scientific discussions. The culture and language of Georgia has changed, enriched and developed in the process of centuries-old history, forming unique customs and traditions. At the same time, the issue of national dress in the historical and cultural aspects, its connection with national identity was rarely considered in publications. It was emphasized that the Georgian national costume reveals cultural traditions, history, beliefs, ideas about the beauty of the Georgian people.

Key words: culture, language, nation, identity, Georgian people, national costume, Georgian writing, agglutinative language.
\end{abstract}

\section{[Д.Я. Гордиенко, Э.А. Иманмагомедова, А.И. Акавова Особенности культуры и языка грузин- ского народа]}

Культура состоит из множества элементов. Одни из элементов, составляющих культуру более очевидны, другие менее: одежда, язык, еда, обычаи, убеждения, ценности, религиозные верования, суеверия и т.п. В последние годы наблюдается рост академического интереса к культуре и наследию стран Причерноморья. Усиление акцентов и интереса в вопросах национальной идентичности в государствах региона внесли значительный вклад в научные дискуссии. Культура и язык Грузии менялись, обогащались и развивались в процессе многовековой историей, формируя уникальные обычаи и традиции. При этом вопрос о национальной одежде в историческом и культурологическом аспектах, ее связи с национальной идентичностью рассматривался в публикациях редко. Подчеркнуто, что грузинский национальный костюм раскрывает культурные традиции, историю, верования, представления о красоте грузинского народа.

Ключевые слова: культура, язык, нация, идентичность, грузинский народ, национальный костюм, грузинская письменность, агглютинаивный язык.

Dinara Ya. Gordienko - Ph.D. in Philology, Associate Professor, Rostov State University of Economics, Rostov-on-Don, Russian Federation.

Elmira A. Imanmagomedova - Ph.D. in Philology, Dagestan State Medical University, Makhachkala, Dagestan Republic, Russian Federation.

Aida I. Akavova - Ph.D. in Philology, Associate Professor, Dagestan State University of National Economy, Makhachkala, Dagestan Republic, Russian Federation.

Гордиенко Динара Якубовна - кандидат фрилологических наук, доцент, Ростовский государственный экономический университет, г. Ростов-на-Дону, Российская Федерация.

Иманмагомедова Эльмира Алиевна - кандидат филологических наук, Дагестанский государственный медицинский университет, республика Дагестан, Российская Федерация.

Акавова Аида Исламгереевна - кандидат фрилологических наук, доцент, Дагестанский государственный университет народного хозяйства, е. Махачкала, республика Дагестан, Российская Федерация. 
The idea that a nation has a soul was conceptualized by Plato in his book "Republic", in which the philosopher stated that there is a soul in a state that resembles the soul of an individual. "Shouldn't we admit," he said, "that in each of us there are the same principles and habits as in the state (435-E) and that these three distinctive forces perform unique actions within an individual i.e., the Appetite (thirst, hunger, etc. etc.), the Spirited (anger) and the Rational (a reasonable principle) that are transferred to the State "into its" business, protective and deliberative principle" [2].

Archaeological excavations and ancient records have confirmed the presence of numerous tribes that inhabited and migrated through the South Caucasus since the Upper Paleolithic (40-12 thousand years ago) when primitive people began to "explore caves as natural dwellings with ready-made walls and arches. Living in one place contributed to the creation of stable groups of people united by blood ties." One of the Caucasian countries located on the Caucasian Isthmus, which is the watershed between the Black and Caspian Seas, is Georgia [1, p. 3].

In the Merriam Webster dictionary, the formulation of an ethnos is given as:

- the definition of large groups of people classified according to a common racial, national, tribal, religious, linguistic or cultural origin or the origin of ethnic minorities, ethnic enclaves;

- belonging to a certain ethnic group;

- attitude towards ethnic minorities or groups characteristic of them [7].

National identity is also a sense of belonging, but it is not focused on one aspect or aspect of culture, but on broader criteria including origin, language, culture and religion. Language and origin are usually important criteria for national identity. People prefer to build relationships with those who speak the same language and have the same origin. The same language can be considered as primary or secondary. Primary language means common language. People who speak the same main language can communicate with each other without any problems. A country with the same national identity means that its citizens belong to a group with the same language, origin, culture and religion (at least some of the criteria are mostly the same). National and cultural identity is very important for a country as it influences the stability and cohesion of its citizens [12].

A distinctive Georgian identity began to form in the first centuries of the $1^{\text {st }}$ millennium $\mathrm{BC}$. The main factors that influenced the formation of the Georgian ethnos were: the strengthening of the Iberian state in the $1^{\text {st }}$ and $2^{\text {nd }}$ centuries $A D$; adoption of Christianity by Georgians in the $4^{\text {th }}-6^{\text {th }}$ centuries; creation of Georgian writing. The formation of ethnic Georgians was essentially completed in the $6^{\text {th }}-10^{\text {th }}$ centuries. This period was characterized by the strengthening and predominance of the Georgian language, as well as the formation of the state territory and the corresponding cultural development. Thus, the formation of culturally homogeneous areas covering large territories is associated with the emergence of large tribal unions. Mutual communication, exchange of goods and spiritual values - "all this contributes to the further rapprochement of the tribes, paved the way for their merger and the formation of nationalities" [1, p. 8].

Every person is a part of the culture. Everyone is often intrigued by other cultures. Culture is an integral determinant of who we are as a person. The frequently used term culture has countless definitions depending on the direction of research. The level of a speech act implies "both linguistic forms and social norms, and, therefore, is necessarily culturally changeable." However, culture determines what is acceptable and what is unacceptable in any society and for any nation. There are countless historical records, ethnographic and anthropological works that are sources for the study and understanding of the culture of the Caucasus [10, pp. 46-48].

The culture and language of Georgia developed along with the centuries-old history of the people, giving it unique customs and traditions. Although some traditions have long 
been forgotten, there are still many that Georgians cherish and pass on from generation to generation. The main function of language, as a "form of communication" [3, pp. 74-77], is to facilitate interaction between people, and regardless of whether it is widespread or localized, each language has its own place. The Georgian language "creates" the realities shared by the society and "... is used not only as a tool for the exchange of information, but as a symbolic system capable of creating and shaping symbolic realities such as values, perceptions, identities through discourse" [6, pp. 107-124].

The Georgian language belongs to the Kartvelian (South Caucasian) language family. It is related to few other languages and is associated only with Mingrelian, Svan, Laz and Judeo-Georgian, the language of Georgian Jews. The Georgian alphabet or the alphabet that is used to write the Georgian language is called Mkhedruli. The alphabet consists of 33 letters, including 5 vowels and 28 consonants. The Georgian alphabet does not know capital letters. The names of cities, countries or people are written in lowercase letters. The Georgian language itself belongs to agglutinative languages, in which the dominant type of inflection is agglutination (gluing) - adding suffixes at the end of words that change their meaning. Unlike Russian, which has 6 cases, Georgian has one more. Another feature of the Georgian language is that it does not know the grammatical gender. While in Russian, English or German, three genders are known: female, male and neuter, in other languages, such as Italian or Spanish, at least two genders (female and male) are known, in Georgian there is only one form [10, pp. 46-48].

Georgia of the 21st century with its historical and ethnographic provinces and ethnic groups Kartlis, Imereti, Rachin, Lechkhum, Ingiloys, Chveneburi, Pshava, Khevsur, Kakheti, Ajar, Gurians, Fereydan, Mtiuly, Javakhi, Meskheti people, Mochevs) a place where traditions and modernity closely coexist with each other, demonstrating "simultaneous belonging" and "combination of cultures", ethnic groups and a single nation - the Georgian people [5, pp. 50-57].

The tolerant culture of the Georgian people "creates comfortable conditions for the existence and neutralization of aggressive conflict relations" with such a number of ethnic groups living in Georgia and having their own characteristics and characteristics [9, p. 2830]. So, Gurians is praised for their optimistic attitude and light humor. Mingrelians are admired for their shrewdness and skill. Imeretians are famous for their communicative panache. The Kakheti are famous for their agricultural inclinations. The Svans are known especially among the Georgians as skilled hunters and mighty warriors with strong insular inclinations. Rachin are highly skilled shepherds, able to easily overcome the slopes of the Greater Caucasus. Residents of Mtskheta-Mtianeti are inveterate climbers, highly demanded the city dwellers of Tbilisi, as a Georgian people, are generally known throughout the world for their hospitality and openness towards foreigners. Adjarians are known for their adherence to the traditional way of life while remaining incredibly tolerant of peoples of other cultures and religions. The people of Shida Kartli are revered for their steadfastness and perseverance in the face of adversity.

Although "language forms thoughts, demonstrates the nature of communication relations," national symbols are no less important for national identity than language. The importance of national symbols may vary depending on the strength, history and political environment of the nation, however, symbols are easily identified and used [11, pp. 36-41].

The culture of Georgia is a set of views, customs of individual ethnic groups living in this territory with a reflected life activity of a person, a group and society as a whole. "The external attributes of belonging to culture are hairstyles, clothes, jewelry, ...." [4, p. 100] For example, the national easily recognizable symbol passing from generation to generation the history and culture of the Georgian people is the national costume. Traditional costumes in Georgia were formed under the influence of the nature and lifestyle of this country. The elements of the national costume identify the Georgian people as people sharing 
their identity, and with the help of tailoring and decoration details show how they differ from their neighbors. Every Georgian man was at the same time a warrior, a farmer and a shepherd. Each woman was (and in most cases remains) a housewife, her distinctive feature is predetermined by the rules of behavior for most Caucasian women - modesty. Traditionally, Caucasian women cannot show their bodies to unfamiliar husbands, only to their husbands. That is why national men's suits are, as a rule, comfortable and warm, and women's suits of Georgian, as well as Caucasian women in general, are usually modest, but at the same time beautiful and feminine. Now these rules are not so strict, but the national dress still reflects Georgian traditions and laws.

The constituent elements of traditional Georgian clothing, widespread until the end of the 19th - beginning of the 20th centuries, included in a man's suit: these are "piranha" (Tshirt), "sharvali" (wide trousers) and "chokha" (jacket). Chokha, a kind of iconic garment of Georgia, is made of wool (black, gray, white, blue, red or brown fabric), has long sleeves and hem, as well as a belt. Chokha always has bandoliers on either side of the chest, places filled with bullet-shaped ornaments called masri. The colour of the chokhi symbolizes a man's place in society. Rich people of princely origin in Georgia wore a kaba - a silk jacket with silky buttons and fasteners on the chest and wrists, "kuladga" - a short jacket made of velvet and decorated with fur and a "papakha" (Georgian hat). In winter, wealthy Georgians wore fur coats decorated with silver and gold. It was not the rich who wore "burkas" (a coat made of howlok), in addition to a winter suit, regardless of the financial component, there was a high karakul hat made of sheepskin.

The shoes of the Georgian people also symbolized the wealth of the owner. Rich people (men and women) used "koshi" (high-heeled armor-boots), "tsagi" (high leather boots) and "meti" (soft shoes without a heel) Poor people used shoes made of rawhide skin. The symbol of the male Georgian costume, regardless of class, is a weapon (saber, knife). The richer a person is, the better his weapon is [8].

Traditional women's clothing in Georgia is "kartuli" (a long dress with a tight belt), richly decorated with a bodice and decorated with a long belt. The symbolism of a Georgian woman is also contained in her headdress, which consists of "lechaki" (a triangular white veil of tulle), "kopi" (a thin roll of silk or cotton), "chikhta" (a cardboard headband trimmed with velvet), "baghdadi" (a dark scarf) and "chadri" (a large chintz veil covering the entire body except for the face or only the eyes) [8].

Georgian national costume shows the history of the Georgian nation and reveals an understanding of their traditions, beliefs and ideas about beauty. National dress makes it possible to identify and compare countries with a similar or common history or heritage. Georgian national dress, Georgian language, and national identity have significant differences, and thus arouse the interest of scientists and researchers.

\section{Лumepamypa}

1. Бердзенишвили Н.А., Дондуа В. Д., Думьадзе М.К., Меликишвили Г.А., Месхиа Ш.А. История Грузии: с древнейших времен до 60-х годов 19 века. Тбилиси: Государственное издательство учебно-педагогической литературы, 1962, 253 С. URL: http://dspace.nplg.gov.ge/bitstream/1234/3051/1/Istoria_Gruzii_tom_I.pdf.

2. Перуанский C.C. В защиту великих: Трактат о том, как знаменитые фрилософы трактуют великих. Книга первая. Платониана. М.: РГО, 2005. 168 C. URL: http://social-gumanizm.narod.ru/platoniana.htm

3. Петрова Ю.А. Знаково-символические системы как часть семиотических систем в молодежных субкультурах // Гуманитарные и социально-экономические науки. 2019, № 3 (106). 
4. Петрова Ю.А. Репрезентация ценностей молодежной субкультуры в ценностносмысловом пространстве языка. Дис. канд. филос. н. 2012.

5. Петрова Ю.А. Многокультурность и межкультурность, культура и язык в XXI веке // Гуманитарные и социальные науки. 2019. № 4.

6. Kramsch C. Context and culture in language teaching, Oxford University Press; Illustrated edition. 1993. 107-124 P. 304 P.

7. Merriam Webster dictionary. URL: https://www.merriam-webster.com/dictionary/ethnic.

8. National men and women clothing in Georgia. URL: http://nationalclothing.org/europe/14-georgia/2-national-men-and-women-clothing-ingeorgia.html.

9. Petrova Y.A., Filina A.A. Highly developed culture of tolerance as the factor of the favorable personality development. Materials of the IV international scientific conference. 2017. 28-30 P.

10. Petrova Yu.A. Language conscious as the peculiarity of cultural differences. Научный альманах стран Причерноморья. 2016. № 2 (6). 46-48 С.

11. Petrova Yu., Kemova M. Adygea is a pearl of the Caucasian, national features of ethnos from origins to modernity. Научный альманах стран Причерноморья. 2019. № 4 (20). 36-41 C.

12. Yu Ching W. Culture, society and the state in Asia, Communication studies in Hong Kong, 2007. URL: https://hkuspace1.wordpress.com/.

\section{References}

1. Berdzenishvili N.A., Dondua V. D., Dum'adze M.K., Melikishvili G.A., Meskhia Sh.A. Istoriya Gruzii: s drevneyshikh vremen do 60-kh godov 19 veka. Tbilisi: Gosudarstvennoye izdatelstvo uchebno-pedagogicheskoy literatury [History of Georgia: from ancient times to the 60s of the 19th century. Tbilisi: State Publishing House of Educational and Pedagogical Literature]. 1962. 253 p. Available at: http://dspace.nplg.gov.ge/bitstream/1234/3051/1/Istoria_Gruzii_tom_I.pdf. (In Russian).

2. Peruanskiy S.S. V zashchitu velikikh: Traktat o tom, kak znamenityye filosofy traktuyut velikikh. Kniga pervaya. Platoniana. [In Defense of the Greats: A Treatise on How Famous Philosophers Interpret Greats. Book one. Platoniana]. Moscow: RGO. 2005. 168 p. Available at: http://social-gumanizm.narod.ru/platoniana.htm (In Russian).

3. Petrova Yu.A. Znakovo-simvolicheskiye sistemy kak chast' semiotiche-skikh si-stem v molodezhnykh subkulturakh [Sign-symbolic systems as part of semiotic systems in youth subcultures Gumanitarnyye i sotsialno-ekonomicheskiye nauki. 2019, No. 3 (106) (In Russian).

4. Petrova Yu.A. Reprezentatsiya tsennostey molodezhnoy subkultury $v$ tsennostnosmyslovom prostranstve yazyka. [Representation of the values of the youth subculture in the value-semantic space of the language]. Dis. Cand. Philos. n. 2012. (In Russian).

5. Petrova Yu., Mnogokulturnost i mezhkulturnost, kultura i yazyk v XXI veke [Multiculturalism and interculturality, culture and language in the XXI century]. Gumanitarnyye i sotsialnyye nauki. 2019. No. 4. (In Russian).

6. Kramsch C. Context and culture in language teaching, Oxford University Press; Illustrated edition, pp. 107-124. 1993. 304 p. 
7. Merriam Webster dictionary. Available at: https://www.merriamwebster.com/dictionary/ethnic.

8. National men and women clothing in Georgia. Available at: http://nationalclothing.org/europe/14-georgia/2-national-men-and-women-clothing-ingeorgia.html.

9. Petrova Y.A., Filina A.A. Highly developed culture of tolerance as the factor of the favorable personality development. Materials of the IV international scientific conference, 2017, pp. 28-30.

10. Petrova Yu.A. Language conscious as the peculiarity of cultural differences. Science Almanac of Black Sea Region Countries. 2016. No. 2 (6). pp. 46-48.

11. Petrova Yu., Kemova M. Adygea is a pearl of the Caucasian, national features of ethnos from origins to modernity. Science Almanac of Black Sea Region Countries. 2019. No. 4 (20). pp. 36-41.

12. Yu Ching W. Culture, society and the state in Asia, Communication studies in Hong Kong. 2007. Available at: https://hkuspace1.wordpress.com/. 